\title{
AS IMAGENS PRIMORDIAIS E SUA RELAÇÃO COM O ESPAÇO CITADINO NA POESIA DE PABLO NERUDA ${ }^{3}$
}

\section{THE PRIMORDIAL IMAGES AND THEIR RELATIONSHIP WITH THE CITY SPACE IN PABLO NERUDA'S POETRY}

\author{
Ximena Antonia DÍAZ MERINO
}

\begin{abstract}
RESUMO: A obra nerudiana abordada neste estudo remete a três cidades chilenas: Тетисо, cidade rural que na época do poeta ainda estava em processo de colonização; Santiago, capital do Chile em plena expansão urbana na segunda década do século XX e Valparaíso, um dos portos mais importantes do Chile. As relações estabelecidas entre o sujeito poético e os espaços mencionados revelam uma identificação total com o território do sul, uma rejeição à capital e uma aceitação imediata da região portuária, resultando desta interação um diálogo ou sua negação entre o espaço observado e o sujeito poético. Serão objeto de reflexão as imagens que surgem das vivências diretas do poeta ao habitar esses espaços, assim como suas experiências primigênias resgatadas pela memória. O tempo histórico abordado abrange as primeiras sete décadas do século XX. O questionamento sobre estes espaços será feito a partir da análise da palavra e da imagem poética que revelará as modificações e experiências do ser provinciano de Тетисо nos novos territórios por ele habitados, tendo sempre como referência a região sul para com Santiago e Valparaíso.
\end{abstract}

PALAVRAS-CHAVE: Poesia moderna; Pablo Neruda; Cidade; Memória; Imagem poética.

ABSTRACT: The Neruda's work addressed in this study refers to three Chilean cities: Temuco, a rural town that, at the poet's time, was still in the process of colonization; Santiago, the capital of Chile, a booming city in the second decade of the twentieth century; and Valparaíso, one of the most important ports in Chile. The relationships established between the poetic subject and these spaces shows total identification with the southern territory, a rejection of the capital and an immediate acceptance of the port area, resulting in a dialogue, or its negation, between the space and the poetic subject. Some reflections are made on the images that arise from the direct experiences of the poet when inhabiting these spaces, as well as his primordial experiences recalled by the memory. The historical period covered in this study includes the first seven decades of the twentieth century. The questioning of the spaces results from the analysis of the

\footnotetext{
${ }^{3}$ O presente texto faz parte da tese de Doutorado intitulada Pablo Neruda e o olhar poético sobre as cidades chilenas: Temuco, Santiago e Valparaíso. Programa de Pós-Graduação em Letras Neolatinas da Universidade Federal do Rio de Janeiro, 2008.

4 Centro de Ciências Humanas, Educação e Letras - Universidade Estadual do Oeste do Paraná (UNIOESTE) - Marechal Cândido Rondon - PR - Brasil - CEP 85960-000 - xdmerino@ig.com.br
} 
word and the poetic image, which shows the changes and experiences of the provincial person from Temuco in the new territories inhabited by him, always with reference to the southern in relation to Santiago and Valparaíso.

KEYWORDS: Modern poetry; Pablo Neruda; City; Memory; poetic image.

Que tensão de infâncias deve estar de reserva no fundo do nosso ser para que a imagem de um poeta nos faça reviver subitamente as nossas lembranças, reimaginar nossas imagens a partir de palavras bem reunidas! Porque a imagem de um poeta é uma imagem falada, e não uma imagem que os nossos olhos vêem. Um traço de imagem falada basta para nos fazer ler o poema como eco de um passado desaparecido.

Gaston Bachelard (1988a, p.110).

A identificação das imagens primordiais nerudianas será realizada à luz de Gilles Deleuze, que em sua obra Proust e os signos (2003) identificou quatro tipos de signos: os mundanos, os amorosos, os materiais e os signos da arte. Neste estudo serão abordados os signos materiais ou essenciais que remetem ao mundo das impressões ou das qualidades visíveis. Estes signos, também chamados de sensíveis, de acordo com Deleuze, uma vez experimentados proporcionam uma estranha alegria.

Em Neruda podemos identificar elementos materiais que aparecem reiteradas vezes nos seus escritos dedicados às cidades chilenas em que viveu: madeira, chuva, vento, terra, árvores, sinos, casa, raízes, rios, dentre outros. Elementos relacionados com sua origem, arquétipos que o remetem ao espaço sulista de sua infância e adolescência da cidade de Tетисо, e que voltam a surgir no presente urbano e portuário na cidade de Valparaíso. A constante reincidência das imagens primordiais na obra de Pablo Neruda se deve, como explica Bachelard (1988a, p.119), a que "Cada arquétipo é uma abertura para o mundo, um convite ao mundo [...] A água da criança, o fogo da criança, as árvores da criança, as flores primaveris da criança [...]" permanecem vivos e sempre estão a reclamar um poema.

A obra nerudiana abordada neste estudo remete a três cidades chilenas: Teтисо, cidade rural que na época do poeta ainda estava em processo de colonização; Santiago, capital do Chile em plena expansão urbana na segunda década do século XX e Valparaíso, um dos portos mais importantes do Chile. As relações estabelecidas entre o 
sujeito poético e os espaços mencionados revelam uma identificação total com o território do sul, uma rejeição à capital e uma aceitação imediata da região portuária, resultando desta interação um diálogo ou sua negação entre o espaço observado e o sujeito poético.

Serão objeto de reflexão as imagens que surgem das vivências diretas do poeta ao habitar esses espaços, assim como suas experiências primigênias resgatadas pela memória. O tempo histórico abordado abrange as primeiras sete décadas do século XX. O questionamento sobre estes espaços será feito a partir da análise da palavra e da imagem poética que revelará as modificações e experiências do ser provinciano de Teтисо nos novos territórios por ele habitados, tendo sempre como referência a região sul para com Santiago e Valparaíso.

\section{Temuco: a paisagem primigênia}

[...] se há algo que inevitavelmente se foi, há, entretanto, alguma coisa que fica. O que fica das pegadas no chão da memória? Fica o que significa $[\ldots]$ ou o que significa passa a ficar?

Guilles Deleuze (1994, p.11-12).

Ao compreender o significado dos arquétipos segundo o raciocínio desenvolvido por Gaston Bachelard (1988a, p.120) como

[...] reservas de entusiasmo que nos ajudam a acreditar no mundo, a amar o mundo, a criar o nosso mundo [...] $\mathrm{O}$ arquétipo está ali, imutável, imóvel sob a memória, imóvel sob os sonhos. E, quando se faz reviver, pelos sonhos, o poder do arquétipo da infância, todos os grandes arquétipos das potências paternas, das potências maternas retomam a sua ação [...] Tudo o que acolhe a infância tem uma virtude de origem. E os arquétipos permaneceram sempre como origens de imagens poderosas.

E uma vez que o olhar retrospectivo é uma constante na obra de Pablo Neruda, é possível interpretar, através da identificação de suas imagens primordiais ou arquétipos, o mundo imagético manifestado no canto às cidades que configuram a tríade citadina aqui abordada - Temuco, Santiago e Valparaíso. Em Neruda a rememoração pode ser compreendida como o desejo de preservar as vivências que constituem a base de sua identidade, uma tentativa de "encontrar o tempo perdido e fixá-lo para sempre, penetrando mais profundamente na atualidade" (JOZEF, 1993, p.38). Chegar-se-á, dessa 
maneira, à dedução de Deleuze de que das experiências da vida somente "Fica o que significa", ou seja, os fatos e elementos que causaram uma impressão no indivíduo. Em Neruda isto se constata através de uma escrita reincidente nos motivos e paisagens primigênias, já que, como afirma Gaston Bachelard em A poética do devaneio (1988b, p.119),

Nos nossos devaneios voltados para a infância, todos os arquétipos que ligam o homem ao mundo, que estabelecem um acordo poético entre o homem e o universo, todos esses arquétipos são, de certa forma, revivificados.

Pode-se deduzir, então, que o "acordo poético" dos arquétipos é a força de síntese que possui a poesia para expressar a existência humana.

Num primeiro estágio, o olhar retrospectivo acontece em Neruda como mecanismo de defesa para amenizar o presente adverso na capital chilena, como registrado no poema "Aromos rubios en los campos de Loncoche" de Crepusculario (NERUDA, 1977, p.46-47):

Yo soy una palabra de este paisaje muerto, soy el corazón de este cielo vacio; cuando voy por los campos, con el alma en el viento, mis venas continúan el rumor de los ríos.

A dónde vas ahora? - Sobre el cielo la greda del crepúsculo, para los dedos de la noche. No alumbrarán estrellas... A mis ojos se enredan aromos rubios en los campos de Loncoche ${ }^{5}$.

Desses versos emerge a imagem de uma paisagem estática e sem vida coroada por um céu sem estrelas, ambiente que faz com que o eu-lírico volte automaticamente à paisagem viva e cheia de movimento da região da Araucanía, "cuando voy por los campos, con el alma en el / viento, / mis venas continúan el rumor de los ríos". O sujeito lírico experimenta através do olhar retrospectivo a cor, o cheiro e a textura dos milenares "aromos ${ }^{6}$ rubios en los campos de Loncoche", uma maneira de respirar o passado, a melancolia de uma infância habituada ao cheiro da chuva, dos bosques,

\footnotetext{
${ }^{5}$ Loncoche, que em mapuche significa "cabeça de homem importante", é uma cidade do sul do Chile localizada na região da Araucanía.

${ }^{6}$ Árvore de galhos espinhosos e flores amarelas muito cheirosas, que podem chegar a medir até dezessete metros de altura (LAROUSSE, 1997, p.95).
} 
enfim, da natureza. Este mecanismo de defesa é explicado por Bachelard (1988, p.97112), da seguinte maneira:

Nossa adesão à beleza primeira foi tão forte que, se o devaneio nos transporta às nossas mais caras lembranças, o mundo atual parece totalmente descolorido [...].

A Infância vê o Mundo ilustrado, o Mundo com suas cores primeiras, suas cores verdadeiras. O grande outrora que revivemos ao sonhar nossas lembranças de infância é o mundo da primeira vez. Todos os verões de nossa infância testemunham o 'eterno verão'.

Num segundo momento, o resgate da memória serve de referência para explicar o sentimento de identificação e complementação que significou para Neruda (2000, p.73) interagir com o espaço portuário de Valparaíso:

En el punto más desordenado de nuestra juventud nos metíamos de pronto, siempre de madrugada, siempre sin haber dormido, siempre sin un centavo en los bolsillos, en un vagón de tercera clase. Éramos poetas o pintores de poco más o poco menos de veinte años, provistos de una valiosa carga de locura irreflexiva que quería emplearse, extenderse, estallar. La estrella de Valparaíso nos llamaba con su pulso magnético.

Constata-se, então, que em Neruda as vivências significativas da infância e da adolescência constituem o "poço de seu ser", , ou seja, o reservatório que contém suas raízes identitárias, suas referências culturais e pessoais. Portanto, é a identificação das imagens primordiais presentes nos textos citadinos o que possibilitará a interpretação do mundo imagético resultante da rememoração.

Um dos signos materiais que surgem com frequência nos versos nerudianos revela-se na imagem da ferrovia, meio de transporte que serviu de nexo entre as diferentes cidades que o poeta percorreu nas primeiras décadas do século XX. Meio de transporte que desde o século XIX foi o símbolo do progresso e da prosperidade que a revolução industrial trouxe ao mundo. No Chile a ferrovia como ideia coletiva se desenvolveu historicamente como a coluna vertebral da nação, produto da industrialização. Este meio de transporte teve grande importância tanto nas cidades quanto nas províncias, onde a população se organizava ao redor de suas estações ferroviárias sem diferenciar classes sociais. Na cidade as famílias privilegiadas viam na

\footnotetext{
${ }^{7}$ Termo empregado por Bachelard para referir-se ao reservatório da memória que vai registrando as experiências e os elementos da primeira idade. Estas lembranças ficam armazenadas no fundo do ser prontas para ser resgatadas e revividas (BACHELARD, 1988b, p.110).
} 
estação um lugar de encontro e distração e as mães de proles numerosas levavam seus filhos à estação para passear. Na província era um acontecimento a chegada dos familiares vindos de Santiago, as despedidas depois de um verão de férias no campo. Hoje ramais ferroviários sem uso constituem peças de museu com seus trilhos enferrujados misturados à grama; são ruínas de um passado de intensa atividade.

Em seu auge as linhas ferroviárias foram símbolos das viagens, época em que o itinerário era tão importante quanto o destino, já que a prazerosa viagem de trem permitia ao passageiro admirar através das janelas a sucessão interminável de paisagens, como o confirma Neruda (2000, p.39-40) ao relatar sua primeira viagem de Тетисо a Santiago:

Provisto de un baúl de hojalata, con el indispensable traje de poeta, delgadísimo y afilado como un cuchillo, entré en la tercera clase del tren nocturno que tardaba un día y una noche interminables en llegar a Santiago [...] Entre tanto el tren pasaba, de los campos con robles y araucarias y las casas de madera mojada, a los álamos del centro de Chile, a las polvorientas construcciones de adobe. Muchas veces hice aquel viaje de ida y vuelta entre la capital y la provincia, pero siempre me sentí ahogar cuando salía de los grandes bosques, de la madera maternal [...].

Em seu relato o jovem poeta registra o significado afetivo do sul; observa-se também a presença de alguns dos elementos que configuram seu mundo primigênio: as árvores e a casa materna, ao tempo que declara a dificuldade de deixar para trás seu universo de "campos con robles y araucarias y las casas de madera mojada" e ter que penetrar nas "polvorientas construcciones de adobe" da capital.

As ferrovias faziam parte da paisagem cotidiana do jovem Neruda desde sua infância. Seu pai era ferroviário e dirigia um trem lastrero em Temuco, e às vezes Neruda tinha a sorte de poder acompanhar seu pai nas viagens até os povoados vizinhos, ocasiões em que o jovem poeta entrava em contato direto com a natureza e aproveitava para fazer suas explorações: "La naturaleza allí me daba una especie de embriaguez. Me atraían los pájaros, los escarabajos, los huevos de perdiz” (NERUDA, 2000, p.13). Foi assim que a natureza do sul do Chile entrou para sempre na vida e obra de Pablo Neruda. O trem, que sempre foi uma imagem significativa na infância de Neruda, se tornou também o elo entre as cidades de Temuco, Santiago e Valparaíso.

Cabe destacar que a casa ocupa na obra de Neruda um lugar importante porque nela o poeta materializou as imagens que constituem sua identidade primigênia. Se nos 
versos nerudianos os signos sensíveis que configuram seu mundo primeiro são revelados pela palavra poética, em suas casas essas imagens se materializam configurando uma poesia que se revela nas formas e nos objetos amados. Dessa maneira, as casas nerudianas se apresentam como espaços reveladores de formas caprichosas cujos cômodos decorados com objetos de estimação são verdadeiros poemas geradores de felicidade ao seu morador-reconstrutor. Conforme Gaston Bachelard (1993, p.34-35):

[...] existe para cada um de nós uma casa onírica, uma casa de lembrança-sonho, perdida na sombra de um além do passado verdadeiro [...] Habitar oniricamente a casa natal é mais que habitá-la pela lembrança; é viver na casa desaparecida tal como ali sonhamos um dia.

Ao observar as moradas de Neruda percebe-se que a casa não é um espaço imutável nem estático, pelo contrário, as propriedades adquiridas e reconstruídas pelo poeta permaneceram em constante crescimento, transformação e aperfeiçoamento. $\mathrm{O}$ fato de que o poeta chileno nunca tenha dado por terminadas suas casas, aprimorando-as eternamente, criando novas habitações ou acrescentando detalhes caprichosos, reflete, talvez, a imagem fixada em sua memória das casas temucanas. Construções sempre incompletas e em constante transformação, cena lembrada por Neruda (2000, p.15) em Confieso que he vivido:

Las casas nuestras tenían, pues, algo de campamento. O de empresas descubridoras. Al entrar se veían barrica, aperos, monturas, y objetos indescriptibles.

Quedan siempre habitaciones sin terminar, escaleras inconclusas. Se hablaba toda la vida de continuar la construcción.

Da casa materna localizada no centro da cidade de Parral onde os pais de Neruda viveram até seu nascimento, ou do lar dos avós no sítio Belén onde viveu até os dois anos de idade, nada ficou na memória do poeta chileno. A descrição feita no texto supracitado corresponde à segunda morada de Neruda localizada na rua Lautaro $\mathrm{n}^{\mathrm{o}} 146$ a poucos metros da Estación de Ferrocarriles de Temuco, e foi nessa morada onde escreveu seus primeiros poemas.

Foi o próprio Neruda que se encarregou de procurar os materiais para a reconstrução de suas casas. Participou dos projetos arquitetônicos e foi uma 
preocupação constante a seleção e aquisição de objetos para compor os interiores de suas moradas.

No Chile Neruda adquiriu cinco propriedades: Michoacán, La Chascona e La Manquel, em Santiago; a casa de Isla Negra e La Sebastiana em Valparaíso. Todas elas propriedades com construções simples ou sem acabar que foram sendo reconstruídas pouco a pouco, até tomar as formas e o estilo que as caracterizaria. Das cinco propriedades, três foram conservadas como museus: La Chascona, La Sebastiana e Isla Negra, testemunhos da criatividade e da maneira de habitar de Pablo Neruda. Casas que foram objeto de poemas e nomes muito representativos, que revelam o profundo amor que Neruda depositou nelas.

Nas casas de Pablo Neruda persiste uma constante incansável: o empenho de recriar nelas - tanto interior quanto exteriormente - as moradas e a natureza sulista que o cercaram na infância e na adolescência. Podem-se destacar de Michoacán e de La Chascona os grandes pátios interiores que comunicavam os inúmeros cômodos das casas. Os pátios interiores das casas temucanas intercomunicavam várias casas familiares. Neruda (2000, p.14) descreveu sua casa provinciana com as seguintes palavras:

Es difícil dar una idea de una casa como la mía, casa típica de la frontera, hace sesenta años.

En primer lugar los domicilios familiares se intercomunicaban. Por el fondo de los patios, Los Reyes y los Ortegas, los Candia y los Moson se intercambiaban herramientas o libros, tortas de cumpleaños, ungüentos para fricciones, paraguas, mesas, sillas.

Neruda revelou seu apego às casas onde morou, assim como aos objetos que as decoravam: restos de naufrágios, objetos trazidos do mundo todo e especialmente do saudoso Tетисо. As residências de Neruda revelam o modo de ser e de habitar; elas contêm a imagem do mundo nerudiano, a alma do poeta.

\section{Santiago de Chile: um mar desconhecido}

De la pensión de la calle Maruri me retiré como un molusco que sale de su concha. Me despedí de aquel caparazón para conocer el mar, es decir, el mundo. El mar desconocido eran las calles de Santiago, apenas entrevistas mientras caminaba entre la vieja escuela universitaria y la despoblada habitación de la pensión de familia. 
Pablo Neruda (2000, p. 41).

Neste momento se procederá à apresentação de alguns textos nerudianos - lírica e prosa - que fazem patente a crítica à vida que assume o homem citadino, assim como a presença da paisagem provinciana na urbe santiaguina. Sabendo que as ruas de Santiago eram, de acordo com o próprio Neruda, "un mar desconocido", cheio de mistérios e perigos ao qual se aventurou desprovido de qualquer proteção, "Me despedí de aquel caparazón para conocer el mar", para enfrentar as adversidades com seu único instrumento de defesa, as palavras. Foi valendo-se delas que escreveu, sob um olhar crítico, um discurso poético que retrata a vida urbana através do qual se faz possível uma aproximação à realidade citadina chilena do 1900.

Começar-se-á com a leitura de dois textos nerudianos publicados na revista Claridad sob o título de "Glosas de la Ciudad I". Textos que saíram à luz em agosto de 1921, somente três meses após a chegada de Neruda à capital. No primeiro texto o poeta registra sua visão da massa urbana:

\section{Ciudad.}

Los brazos caen a los lados, como aspas cansadas. Son muchos. Van juntos, las anchas espaldas, las miradas humildes, los trajes deshechos, todo es común, todo es carne de un solo cuerpo, todo es energía rota de un solo cuerpo miserable que parece llevan la tierra entera. ¿Por qué estos hombres que van juntos, tocándose las espaldas robustas, no llevan los vigorosos brazos levantados, no levantan hacia el sol la cabeza? ¿Por qué, si van juntos y tienen hambre, no hacen temblar los pavimentos de piedra de la ciudad, las gradas blancas de las iglesias, con el peso sombrío de sus pisadas hambrientas, hasta que la ciudad se quede inmóvil, escuchando el rumor enorme de las pisadas que treparían hasta cegar el fuego de las fábricas, hasta encender el fuego de los incendios? ¿Por qué estos hombres no levantan los brazos siquiera? (NERUDA, 2001, p.252).

No texto supracitado, o poeta apresenta uma multidão de seres que avança com o olhar fixo no chão, sem ouvir nem sentir o que se passa ao seu redor. Não há diferença entre os indivíduos, todos parecem iguais: "miradas humildes, los trajes deshechos, todo es común, todo es carne de un solo cuerpo". Seres fortes e vigorosos, mas tristes e passivos, homens sem expressão que não lutam por seus direitos e se submetem à exploração trabalhista. Ante esta cena o jovem poeta interroga: “ ¿Por qué, si van juntos y tienen hambre, no hacen temblar los pavimentos de piedra de la ciudad [...] ¿Por qué 
estos hombres no levantan los brazos siquiera?" - um sujeito poético que expressa sua inconformidade ante a atitude alienada do homem urbano.

Se no primeiro texto Neruda (2001, p.254) apresenta sua visão da massa urbana, já no seguinte dirige seu inconformismo a um indivíduo em particular, um "tu" que lhe é familiar, e lhe diz:

\section{Empleado}

Es claro no lo sabes, pero conozco tu vida, entera. Así, sin que me oculten las alegrías raras o los disgustos de todos los días. Sé tu vida febril: de la cama a la calle, de ahí al trabajo. El trabajo es oscuro, torpe matador. Después el almuerzo, rápido. Y al trabajo otra vez. Después la comida, el cuerpo extenuado y la noche que te hace dormir. Ayer, mañana, pasado, sucedió y sucederá lo mismo. La misma vida, es decir, lo que tú llamas vida [...] Nosotros lo llamamos explotación, capital, abuso. Los diarios que tú lees, en el tranvía, apurado lo llaman orden, derecho, patria, etc. Tal vez te halles débil. No. Aqui estamos nosotros, nosotros que ya no estamos solos, que somos iguales a ti; y como tú explotados y doloridos pero rebeldes [...] Hay que decirlo. Por que no sólo el que no obra como piensa, piensa incompletamente. También el que no lo dice...

No escrito lido, a crítica ao comportamento do sujeito citadino submisso é clara e direta. Neruda chama a atenção para que este homem acorde do comportamento mecânico e proteste contra a rotina do trabalho exploratório ao que está submetido, “Ayer, mañana, pasado, sucedió y sucederá lo mismo. La misma vida, es decir, lo que tú llamas vida". Termina incentivando-o a alçar a voz e o lembra de que não está sozinho nessa luta, "Aquí estamos nosotros, nosotros que ya no estamos solos".

Um fato importante a destacar é que a denúncia feita à vida citadina é realizada em tempo presente, ou seja, o poeta forma parte da vida desses indivíduos e ciente disso aproveita a oportunidade de fazer públicas suas reflexões através da revista, possibilitando, com isto, que seus leitores tomem consciência da realidade social em que vivem.

Mas, não é somente na prosa que Neruda registra suas inquietudes, em poemas como “Caballero solo" (NERUDA, 1958, p.69-70), de Residencia en la Tierra, também deixa constância seus questionamentos:

Los jóvenes homosexuales y las muchachas amorosas,

y las largas viudas que sufren el delirante insomnio,

y las jóvenes señoras preñadas hace treinta horas,

y los roncos gatos que cruzan mi jardín en tinieblas, 


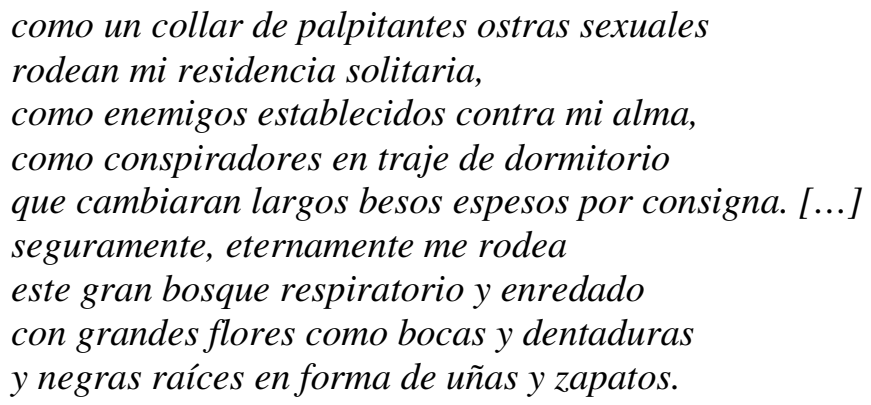

Nos versos citados, observa-se um sujeito lírico sufocado por comportamentos vazios que não fazem parte de seu universo, tipos humanos que o aprisionam, uma aglomeração de elementos e situações que o sufocam. O poeta associa a massa humana a um grande bosque, mas não se trata dos bosques do sul, cheios de árvores de folhas verdes, madeira fresca e cheirosa, nem das raízes que testemunham o passo do tempo. $\mathrm{O}$ bosque urbano é composto de "bocas y dentaduras y negras raíces en forma de uñas y zapatos", uma representação metonímica do homem moderno que se encontra fragmentado, cuja cena bem poderia compor uma tela cubista. Além de remeter ao cubismo, a imagem que emerge dos versos faz lembrar a célebre frase de Marx popularizada por Marshall Berman, "Tudo que é sólido desmancha no ar" - frase que sintetiza o conceito de modernidade como o "turbilhão" que engole o homem mantendo-o num permanente estado de desintegração.

\section{O cotidiano dos bairros santiaguinos sob o olhar nerudiano}

[...] a cidade não conta seu passado, ela o contém como as linhas da mão, escrito nos ângulos das ruas, nas grades das janelas, nos corrimãos das escadas, nas antenas dos pára-raios, nos mastros das bandeiras, cada segmento riscado por arranhões, serradelas, entalhes, esfoladuras ${ }^{\square}$

Italo Calvino (1990, p.14-15).

As cidades não existem somente como espaço físico, há uma construção citadina edificada com palavras, uma construção que dá forma ao cotidiano urbano através da literatura, possibilitando novas perspectivas para a interpretação da cultura e da identidade do habitante urbano. As cidades têm sido registradas pela escrita desde sua fundação, como no caso da cidade de Santiago do Chile, que permite o rastreamento de uma escrita que remonta à época de sua fundação, no tempo em que ainda era Santiago 
de Nueva Extremadura, época em que seu fundador, Pedro de Valdivia, escrevia ao Imperador Carlos V dizendo:

[...] No mês de abril do ano de mil e quinhentos e trinta e nove me deu o Marquês os suprimentos e cheguei a este vale do Mapocho em finais do ano de 1540. Logo procurei falar com os caciques da terra [...] acreditando sermos quantidade de cristãos, vieram os mais pacíficos e nos serviram bem por cinco ou seis meses e fizeram isso para não perder seus alimentos que tinham no campo, e nesse tempo fizeram nossas casas de madeira e palha com o traçado que lhes entreguei, no lugar onde fundei esta cidade de Santiago del Nuevo Extremo, em nome de V. M., no dito vale, como cheguei em 24 de fevereiro de 1541. [Trad. da autora]. La Serena, 4 de setembro de 1545.

As inúmeras cartas escritas por Valdivia deixaram testemunho do processo fundador da cidade de Santiago, assim como do cotidiano de seus habitantes “[...] e todos cavávamos, arávamos e semeávamos ao mesmo tempo, e estávamos sempre armados e os cavalos com sela [...]" (VALDIVIA, 1545), documentos que demarcam o início da reconstrução do espaço e do cotidiano citadino através da linguagem.

Ao reconhecer que a existência da urbe pode ser reconstruída pelas vozes do passado, considerar-se-ão também a prosa e a poesia citadina de Pablo Neruda como signos culturais possíveis de serem reinterpretados hoje, um tempo histórico distante e alheio ao poeta. Com isto afirma-se que as respostas estão dentro dos muros da cidade; saber olhar é saber ler os signos que ela nos oferece, já que o sentido da cidade está dentro dela mesma como enfatiza Italo Calvino (1990, p.18):

O olhar percorre as ruas como se fossem páginas escritas: a cidade diz tudo o que você deve pensar, faz você repetir o discurso [...] Como é realmente a cidade sobre esse carregado invólucro de símbolos, o que contém e o que esconde, ao se sair de Tamara é impossível saber.

Neruda não apresenta em seus poemas uma visão total das coisas ou situações, ele lança mão de particularidades, de fragmentos que, no seu conjunto, constituirão o seu espaço imagético. O lírico chileno, ao transferir para o poema a sua vivência pessoal, está, ao mesmo tempo, transferindo as tendências de uma época e de um momento histórico. Seu eu poético tem um valor representativo da realidade de que faz parte, suas vivências têm uma significação social, ou seja, representam a coletividade de seu tempo. Neruda, através dos poemas dedicados à cidade de Santiago, apresenta sua 
particular visão da paisagem e do cotidiano urbano. As imagens citadinas que fluem desses poemas revelam, a partir de fragmentos, um mundo imagético construído metonimicamente, isto é, o todo pela parte.

Os vários bairros que constituem a capital chilena são como pequenas aldeias, mundos independentes onde seus habitantes parecem ter esquecido que formam parte de um conjunto maior. Dos inúmeros bairros que configuram a cidade de Santiago cinco destacam-se por sua importância e peculiaridade: San Diego, Estación Mapocho, Estación Central, San Pablo e Recoleta, todos eles com características próprias, como observado por Benjamín Subercaseaux (2005, p.121) na obra Chile o una loca geografia:

San Diego é o bairro dos que ganham a vida no pequeno comércio. San Pablo é o bairro onde se arruína o comércio numa vida pequena. A Estación Central é a mescla de transações de primeira mão dos produtos que chegam do sul e da exploração do provinciano que vem para o norte. [Trad. da autora]

Em “Oda a la calle San Diego" Neruda (1993a, p. 415-419) canta a rua principal do bairro, San Diego, um dos bairros mais característicos e populares da capital chilena. Nesse poema Pablo Neruda retoma os questionamentos estéticos apresentados anos antes reafirmando seu interesse pelas coisas terrenas, pelo cotidiano do ser humano, mantendo um enfoque existencialista. Nessa nova etapa iniciada com Odas elementales (1954), o poeta chileno procurou na realidade a essência das coisas.

A partir desse momento, ao dar uma maior atenção à cidade, o espaço urbano passou a ser o palco onde se desenvolvia o dia-a-dia observado e vivenciado pelo escritor. $\mathrm{O}$ vate transformou em discurso poético os sinais emitidos pelo mundo santiaguino, onde o flâneur nerudiano "lê o espaço público, metonimicamente representado pela rua, como realidade vivida e dinâmica" (GOMES, 1994, p.112).

Observa-se, na ode citada, um sujeito lírico atento, revelador da dicotomia campo/cidade onde os elementos do campo vão aflorando a partir dos elementos urbanos. Já na primeira estrofe fica claro que a temática do poema abordará esses dois ambientes antagônicos:

\author{
Por la calle \\ San Diego \\ el aire de Santiago \\ viaja ao Sur majestuoso [...]
}


Cabe destacar que a poesia nerudiana dedicada ao espaço rural apresenta um bucolismo renovado que não se atém a uma simples descrição do entorno natural, mas uma forma de bucólico que remete às condições sociais e cotidianas da vida rural. De acordo com Raymond Williams o significado original de bucólico sofreu uma grande transformação, já que não apresenta somente uma atenção "voltada para a beleza natural, porém trata-se agora da natureza da observação, e não a do simples camponês que trabalha" (WILLIAMS, 1989, p.36).

$\mathrm{Na}$ ode estudada Neruda se define como "el cronista errante de la calle San Diego", cronista que lê a cidade metonimicamente a partir de um segmento de Santiago como registrado nos versos a seguir destacados:

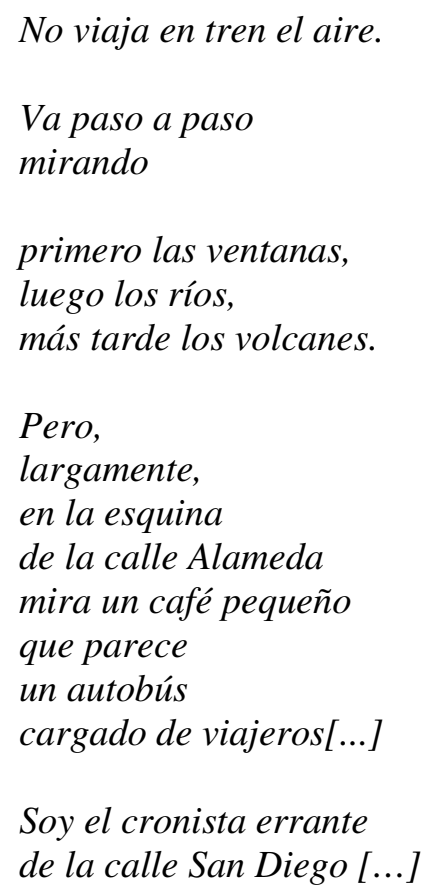

Do poema surgem imagens de elementos cotidianos da paisagem de Santiago, elementos que o vate chileno encontra numa só rua. O poeta-cronista, que à semelhança do flâneur baudelairiano perambula pela cidade de forma dinâmica, observa cada detalhe, cada pedaço desse labirinto de cimento em que se encontra inserido, criando imagens quase aéreas da cidade. Contudo, esta poesia que se completa através da soma de fragmentos pode ser considerada a expressão do traço desintegrador da época vivenciada. Uma aglomeração de objetos isolados e desvinculados de seu todo, uma maneira de traduzir em imagens o espírito fragmentado do homem moderno. No poema 
analisado, Neruda nos apresenta janelas, rios, vulcões, ônibus, selos, utensílios, pernas, braços etc. Elementos arrancados de lugares diversos e que navegam por um tumultuado rio de versos. Esses versos traduzem o modo de ser da realidade santiaguenha na particular visão do poeta chileno:

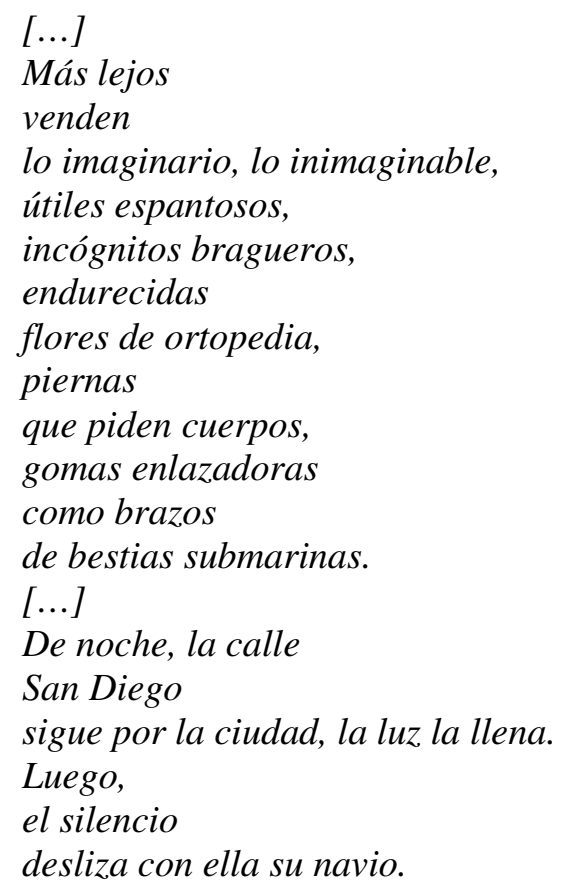

Nesta ode a vida cotidiana é identificada com o rio que corre sem parar, um constante desfazer e refazer, o eterno renascer de cada dia. Um tempo circular presente não somente no mundo físico, mas também na experiência psíquica do homem urbano. Observa-se também que o ritmo santiaguino varia de acordo com as diversas fases do dia e da noite. Embora o ambiente urbano seja o grande motivo da ode, o espaço e as características do mundo rural, estão presentes. Na cidade grande o novo dia é anunciado pelo som do sino:

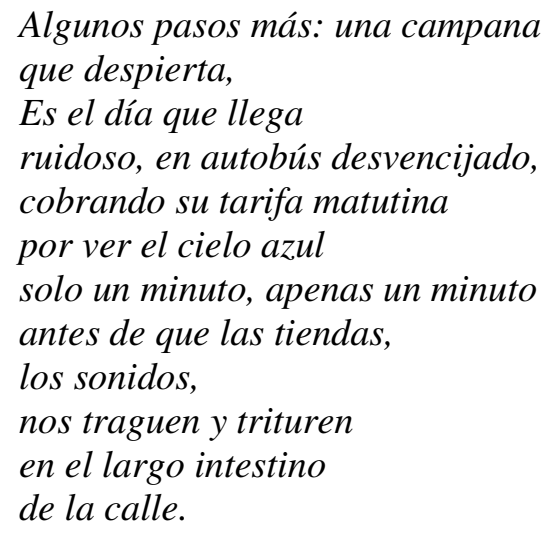


Mas, não é o doce som dos sinos que tocavam diariamente no sul, como lembrado por Eulogio Suárez (2004, p.327): “Aqueles povoados de fundação recente, suas ruas apenas desenhadas, levantadas suas casas, estalavam seus radiantes sinos. Tudo se comunicava naquelas aldeias do Sul do Chile aos golpes do doce metal" ${ }^{\prime}$. Na cidade grande o novo dia é anunciado pelo sino barulhento do "autobús desvencijado, cobrando su tarifa matutina". Neruda em seu canto à cidade nos apresenta um ambiente ameaçador e monstruoso. Para ele a rua é um "largo intestino triturador" que aprisiona. A angústia que atormenta o eu-lírico é amenizada pelo resgate das sensações e das lembranças da terra de nascimento. $\mathrm{O}$ cheiro, o rio, o vento e o frio de outrora tornam mais amena sua permanência no labirinto de concreto:

La calle
corre ahora
hacia arriba,
hacia mañana:
una ola
venida
del fondo
de mi pueblo
en este río
popular
recibió sus afluentes
de toda la extensión del
territorio.

A estratégia utilizada por Neruda para integrar de forma harmônica os dois ambientes antagônicos [campo e cidade] foi a superposição de campos semânticos, ou seja, o vocabulário que procede da natureza é empregado para expressar de forma metafórica a paisagem urbana, onde o movimento citadino é comparado com "una ola" e com um "río", referindo-se assim à massa humana que circula pelas ruas. O mar e os rios, assim como os sinos, são elementos da paisagem primigênia de Neruda que simbolizam suas raízes sulistas.

Contudo, não só os espaços hostis são destacados pelo lírico em "Oda a la calle San Diego", há também ambientes citadinos que parecem dar-lhe conforto, como uma livraria que é comparada com uma "bodega verde" ou com "una nación lluviosa". Livraria que contém obras com imagens de "luna llena, jazmines de archipiélagos: / reinos de nieve", um espaço que remete ao ambiente fresco e acolhedor do sul:

\footnotetext{
${ }^{8}$ Trad. da autora
} 


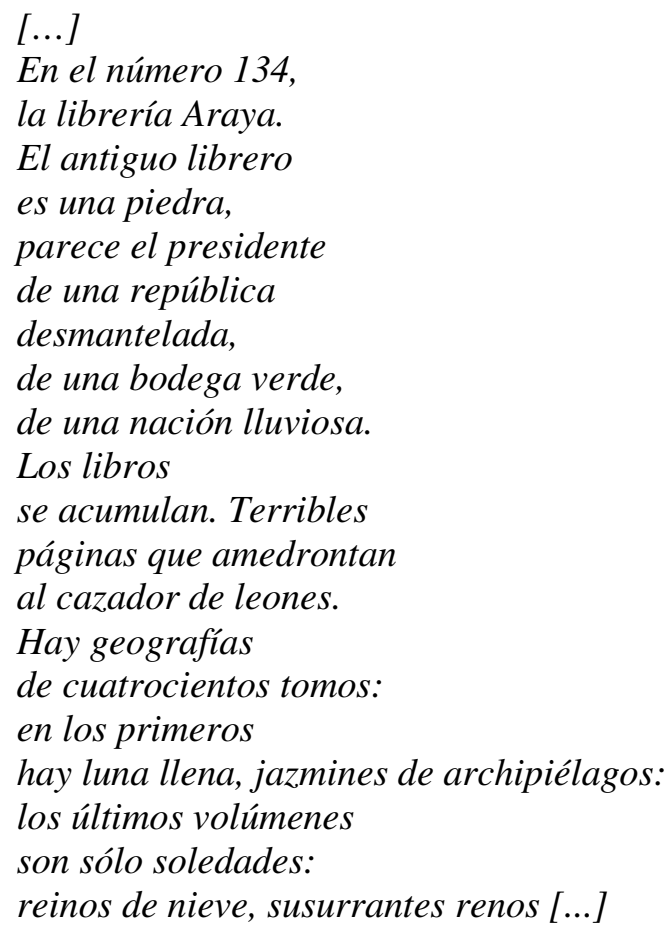

Assim, diante da ausência do espaço rural, Neruda acudirá à sua memória primigênia para textualizar seu vínculo com a terra de nascimento, um vínculo verbal que lhe permite reencontrar-se num território metaforicamente recuperado.

Definir Neruda como um "observador urbano" é apropriado por sua capacidade de penetrar nas realidades física e simbólica da cidade e traduzir em palavras as imagens e vivências do mundo real para o mundo poético. Neruda consegue ouvir o som da cidade, sentir suas dores e suas alegrias, e transporta esses sentimentos para o poema, posto que (RAMA, 1985, p.53):

As cidades desenvolveram uma linguagem mediante duas redes superpostas: a física, que o visitante comum percorre até perder-se na sua multiplicidade e fragmentação, a simbólica que a ordena e interpreta [...] Há um labirinto das ruas que só a aventura pessoal pode penetrar e um labirinto dos signos que só a inteligência raciocinante pode decifrar, encontrando sua ordem.

A representação poética da realidade nerudiana não surge do nada ou de uma inspiração celeste, pelo contrário, é o resultado da soma de experiências do passado e do presente do poeta. Assim, o poema pode ser um caminho que leva a um tipo de conhecimento sobre a realidade, já que o próprio Neruda (2000, p.72) declarou: 
[...] Nos vemos indefectiblemente condenados a la realidad y al realismo, es decir, a tomar una conciencia directa de lo que nos rodea $y$ de los caminos de la transformación [...] si suprimimos la realidad nos vemos de pronto rodeados de un terreno imposible, de un tembladeral de hojas, de barro, de nubes, en que se hunden nuestros pies y se ahoga una incomunicación opresiva.

Conforme as palavras de Benjamín Subercaseaux (2005, p. 121), San Diego é “o bairro dos que ganham a vida no pequeno comércio", característica que não escapou à observação do poeta:

$$
\begin{aligned}
& \text { [...] } \\
& \text { En el siguiente número } \\
& \text { de la calle } \\
& \text { venden pobres juguetes, } \\
& \text { y desde puertas próximas } \\
& \text { la carne asada } \\
& \text { inunda las narices } \\
& \text { [...] } \\
& \text { Más allá venden catres } \\
& \text { de bronce deslumbrante, } \\
& \text { camas descomunales [...] }
\end{aligned}
$$

O realismo apresentado em "Oda a la calle San Diego" pode ser observado na maneira como o eu-lírico se integra ao cotidiano que o rodeia, revelando-se um observador sensível que capta e recebe as mensagens externas e não como um ser que nela se busca. O sujeito lírico se deixa absorver pela rua e tudo o que ele sonha ou imagina é proporcionado por essa realidade. Seu sentimento é coletivo quando escreve:

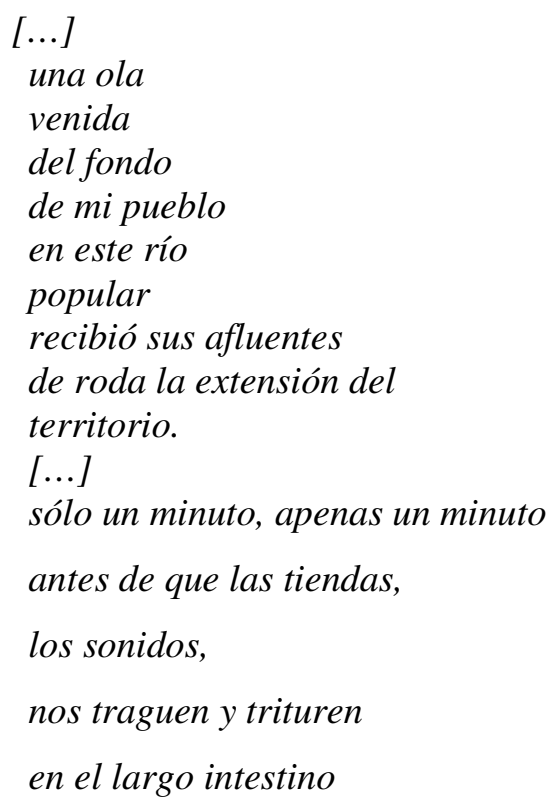


de la calle.

Os versos acima citados revelam um sujeito inserido na multidão quando diz "nos traguen y trituren", não há distanciamento com os habitantes da cidade. O poeta chileno apresenta uma nova maneira de enxergar a realidade urbana se comparado com o flâneur baudelairiano que circulava pela cidade sem se misturar à massa humana, como o afirmou Walter Benjamin (1989, p.50) no texto "Paris do Segundo Império":

$\mathrm{Na}$ Paris de Baudelaire [...] havia o transeunte, que se enfiava na multidão, mas havia também o flâneur, que precisa de espaço livre e não quer perder sua privacidade. Ocioso, caminha como uma personalidade $[\ldots]$.

Enquanto que do convívio diário do cronista nerudiano com o homem citadino surge um sentimento de fraternidade e cumplicidade, o poeta sente a cidade e se inclui nela sem privilégios. Porque como o mesmo Neruda (2003, p.390) registrou: "El poeta no es un 'pequeño dios"', o poeta não é um ser superior aos outros, ao contrário, é um homem comum e somente consciente disso é que sua voz chegará a ser universal.

De acordo com o anteriormente exposto, entende-se que a temática da cidade em Neruda representa uma proposta de redescobrimento das realidades visíveis, um fazer poeticamente consequente com a maneira de ser e pensar do poeta chileno, uma busca pelo entendimento humano. Para Neruda o labor do poeta não se limita a cantar a rosa, a exaltar o amor ou a nostalgia: fazer poesia é isso e muito mais. Neruda (2003, p.392393) cantou também "las ásperas tareas humanas", a impureza da realidade, porque somente dessa maneira "[...] la poesía no habrá cantado en vano".

\section{REFERÊNCIAS}

BACHELARD, G. A poética do devaneio. Tradução de Antônio de Pádua Danesi. São Paulo: Martins Fontes, 1988a.

A poética do devaneio. Tradução de Antônio de Pádua Danesi. São Paulo: Martins Fontes, 1988b.

A poética do espaço. Tradução de Antônio de Pádua Danesi. São Paulo: Martins Fontes, 1993.

BENJAMIN, W. Charles Baudelaire: um lírico no auge do capitalismo. Tradução de José Martins Barbosa e Hemerson Alves Baptista. São Paulo: Brasiliense, 1989 (Obras escolhidas, III). 
BRANCO, L. C. A traição de Penélope. São Paulo: Annablume, 1994.

CALVINO, I. As cidades invisíveis. Tradução de Diogo Mainardi. São Paulo: Companhia das Letras, 1990.

DELEUZE, G. Proust e os signos. Tradução de Antonio Piquet e Roberto Machado. Rio de Janeiro: Forense Universitária, 2003.

DÍAZ MERINO, X. A. Pablo Neruda e o olhar poético dobre as cidades chilenas Temuco, Santiago e Valparaíso. Tese (Doutorado) - Programa de Pós-Graduação em Letras Neolatinas, Faculdade de Letras, Universidade Federal do Rio de Janeiro (UFRJ), Rio de Janeiro, 2008.

GOMES, R. C. Todas as cidades a cidade: literatura e experiência urbana. Rio de Janeiro: Rocco, 1994.

JOZEF, B. Memória, amor e solidão na obra de Pablo Neruda. Revista América Hispânica, Rio de Janeiro: SEPEHA/UFRJ, p.38-46, a.VI, Jul.-Dez. 1993.

NERUDA, P. Crepusculario. 6.ed. Buenos Aires: Losada, 1977. Confieso que he vivido. Barcelona: Ave Fénix, 2000.

. Nerudiana Dispersa (1915-1973). Edición de Hernán Loyola. Barcelona: Galaxia Gutenberg/Círculo de Lectores, 2001 (Obras completas, v. IV).

Residencia en la tierra (1925-1931). Buenos Aires: Losada, 1958.

Obra Completa (1954-1964). Buenos Aires: Ed. Losada, 1993a (v. II). Obra Completa (1966-1973). Buenos Aires: Ed. Losada, 1993b (v. III).

Para nacer he nacido. Buenos Aires: Seix Barral, 2003.

RAMA, Á. A cidade das letras. Introducción de Mario Vargas Llosa y prólogo de Hugo Achugar. Tradução de Emir Sader. São Paulo: Brasiliense, 1985.

SUÁREZ, E. Neruda Total. 3.ed. Santiago: RIL, 2004.

SUBERCASEAUX, B. Chile o una loca geografía. 2.ed. Santiago: Universitaria, 2005.

VALDIVIA, P. Cartas de Pedro de Valdivia que tratan del descubrimiento y conquista del Reino de Chile. Disponível em: http://www.cervantesvirtual.com/servlet/SirveObras/12593842001258285209068/index. htm Data da consulta: 08/08/2011.

WILLIAMS, R. O campo e a cidade na história e na literatura. Tradução de Paulo Henriques Brito. São Paulo: Companhia das Letras, 1989.

Artigo recebido em 08/08/2011 Aceito para publicação em 30/09/2011 